\title{
NATURALEZA JURÍDICA Y CONTROL JURISDICCIONAL DE LAS DECISIONES CONSTITUCIONALES DE EXCEPCIÓN
}

\author{
Legal nature and judicial review of the exceptional \\ constitutional decisions
}

\author{
CARLOS GARRIDO LÓPEZ \\ Universidad de Zaragoza \\ cgarrido@unizar.es
}

\begin{abstract}
Cómo citar/Citation
Garrido López, C. (2017).

Naturaleza jurídica y control jurisdiccional de las decisiones constitucionales de excepción. Revista Española de Derecho Constitucional, 110, 43-73

doi: https://doi.org/10.18042/cepc/redc.110.02
\end{abstract}

\section{Resumen}

La naturaleza jurídica y el control jurisdiccional de las decisiones de declaración y prórroga de los estados de excepción son cuestiones de relevancia constitucional que, en nuestro ordenamiento, han suscitado dudas debido a la diversa formalización de dichas decisiones y a la ausencia de previsión normativa sobre el órgano jurisdiccional encargado de fiscalizarlas. En este trabajo, se analizan las singularidades de los decretos gubernamentales, autorizaciones y resoluciones parlamentarias de excepción que, a juicio de la mayoría de la doctrina, impedían su caracterización bajo una categoría jurídica común. Seguidamente, se identifican los actos simples y complejos que conforman las decisiones excepcionales a efectos de su posible control jurisdiccional. Analizado el marco teórico, se estudian los pronunciamientos contenidos en los AATS que inadmitieron los recursos contra la declaración y la prórroga del estado de alarma decretado en 2010, en el ATC 7/2012, de 13 de enero, y en la trascendental STC 83/2016, de 28 de abril, que, asumiendo la posición doctrinal minoritaria que enmarcaba todos estos actos en una misma categoría, caracteriza sistemáticamente las decisiones de declaración y prórroga de los estados de alarma, excepción y sitio como actos con fuerza de ley solo susceptibles de control de constitucionalidad. 


\title{
Palabras clave
}

Estados de excepción; decisiones excepcionales; actos con fuerza de ley; control de constitucionalidad.

\begin{abstract}
The legal nature and the jurisdictional control of decisions concerning the declaration and extension of states of exception are constitutionally important questions that, in the Spanish legal system, have raised doubts because of the diverse way in which said decisions are formalised and the lack of any legal provision concerning the jurisdictional body responsible for overseeing them. In this study, I will analyse the particular characteristics of governmental decrees, authorisations and parliamentary resolutions concerning exceptions, which, in the judgement of most accepted legal principles, prevented their classification under a common legal category. I will then identify both the simple and complex proceedings that comprise decisions concerning exceptions for the purposes of their jurisdictional control. Once I have analysed the theoretical context, I will study the decisions contained in the Supreme Court cases that did not admit appeals against the declaration and extension of the state of alert decreed in 2010, in the Constitutional Court proceedings 7/2012 of 13th January and in the important Constitutional Court decision 83/2016 of 28th April that, taking a minority position that defined all of these proceedings under one single category, systematically characterises the decisions concerning the declaration and extensions of states of alert, exception and siege as statutory acts that were only subject to constitutional control.
\end{abstract}

\section{Keywords}

States of exception; decisions concerning exceptions; statutory acts; constitutional control. 


\section{SUMARIO}

I. DECISIONES DE EXCEPCIÓN Y ESTADO DE DERECHO. II. DIVERSIDAD DE FORMAS DE DECLARACIÓN Y PRÓRROGA DE LOS ESTADOS EXCEPCIONALES Y AUSENCIA DE PREVISIÓN SOBRE SU CONTROL JURISDICCIONAL. III. POSICIONES DOCTRINALES SOBRE LA NATURALEZA JURÍDICA DE LAS DECISIONES EXCEPCIONALES Y SU CONTROL JURISDICCIONAL: 1. Los decretos gubernamentales de excepción: ¿̇actos políticos o disposiciones reglamentarias? 2. Las autorizaciones y resoluciones parlamentarias de declaración y prórroga de los estados excepcionales: actos parlamentarios con o sin valor de ley. 3. Las decisiones de declaración y prórroga de los estados de alarma, excepción y sitio como actos del estado con fuerza de ley. IV. CARACTERIZACIÓN DE LOS DIVERSOS ACTOS QUE CONFORMAN LAS DECISIONES DE DECLARACIÓN Y PRÓRROGA DE LOS ESTADOS DE EXCEPCIÓN A EFECTOS DEL ART. 27.2.B) LOTC. V. LOS AUTOS DEL TRIBUNAL SUPREMO SOBRE LOS DECRETOS DE DECLARACIÓN Y PRÓRROGA DEL ESTADO DE ALARMA DE DICIEMBRE DE 2010: LA AUTORIZACIÓN PARLAMENTARIA DE LA PRÓRROGA COMO INSÓLITA CAUSA EX POST FACTO DE EXCLUSIÓN DEL CONTROL JURISDICCIONAL DE LA DECLARACIÓN. VI. EL ATC 7/2012, DE 13 DE ENERO, SOBRE EL ACUERDO PARLAMENTARIO DE AUTORIZACIÓN DE LA PRÓRROGA DEL ESTADO DE ALARMA Y SU CONSIDERACIÓN COMO ACTO DOTADO DE EFICACIA JURÍDICA AD EXTRA CON FUERZA DE LEY. VII. LA TESIS DE LA STC 83/2016, DE 28 DE ABRIL, EN LA QUE EL PLENO RECHAZA EL AMPARO DE LOS CONTROLADORES AÉREOS: LAS DECISIONES DE DECLARACIÓN Y PRÓRROGA DE LOS ESTADOS EXCEPCIONALES SON ACTOS CON FUERZA DE LEY SOLO SUSCEPTIBLES DE CONTROL DE CONSTITUCIONALIDAD. VIII. CONSIDERACIONES FINALES. BIBLIOGRAFIA.

\section{DECISIONES DE EXCEPCIÓN Y ESTADO DE DERECHO}

El derecho de excepción pretende hacer frente a las crisis sin renunciar a la fuerza normalizadora del derecho. El control jurisdiccional durante los estados excepcionales es, por ello, posible. Y no solo de las medidas ejecutivas adoptadas por el beneficiario de la concentración de poderes, cuyo control asumen los tribunales ordinarios, sino también de las propias decisiones que declaran la emergencia y activan el régimen excepcional latente en tiempos de normalidad. Y pese al alcance político de esas decisiones de excepción, que han llevado a alguna doctrina a sostener que «les plus importantes doivent échapper au juge» (Camus, 1965: 346), así lo prevén los regímenes constitucionales más avanzados, subrayando, de este modo, frente a la eventualidad de 
la crisis, que la distinción entre poder constituyente y poderes constituidos no solo opera en el momento fundacional, sino que sustenta el orden jurídico incluso en situaciones excepcionales ${ }^{1}$.

La Constitución española de 1978 prevé tres estados con los que responder tasada y proporcionalmente ante situaciones críticas. El control jurisdiccional de las decisiones de declaración y prórroga de estos estados no ha sido, sin embargo, previsto ni constitucional ni legalmente. Y tampoco está clara en nuestro ordenamiento la naturaleza jurídica de estas decisiones excepcionales, cuyo titular y procedimiento de adopción varían dependiendo de la emergencia.

El Gobierno declara el estado de alarma. El Gobierno también prorroga el estado de alarma y declara y prorroga el de excepción, pero previa autorización del Congreso de los Diputados. La declaración y prórroga del estado de sitio corresponde, por su parte, al Congreso. Las decisiones excepcionales adoptan, por ello, una pluralidad de formas: decretos gubernamentales, autorizaciones y resoluciones parlamentarias. Caracterizarlas bajo una categoría común resulta difícil y, procediendo de órganos diversos, intentar residenciar su control en la jurisdicción ordinaria o en la constitucional también lo es.

Durante treinta y dos años, ningún estado excepcional fue declarado, por lo que la referida dificultad no pasó del plano teórico. La transcendencia práctica y el alcance jurídico del problema se evidenciaron, sin embargo, abruptamente con ocasión de la primera declaración de un estado de alarma en España, que se produjo el 4 de diciembre de 2010. Los hechos son conocidos: tras meses de conflicto laboral, la tarde de 3 de diciembre de 2010, los controladores aéreos al servicio de AENA abandonaron de forma concertada y masiva sus puestos en las torres de control de los principales aeropuertos. El espacio aéreo español fue cerrado, cientos de vuelos fueron suspendidos y miles de viajeros se vieron afectados ${ }^{2}$.

1 Es el caso de los controles de constitucionalidad de las decisiones de declaración y prórroga de los estados de excepción previstos en Italia, Francia, Portugal y, especialmente, en Alemania, donde el Tribunal Constitucional Federal puede controlar tanto las decisiones gubernamentales como las leyes federales declaratorias de estados excepcionales a través de diversas vías impugnatorias y sin limitación alguna. En Irlanda, Grecia o Chipre el control jurisdiccional de las decisiones excepcionales también es posible, pero solo por razones de forma, limitado, por tanto, a verificar si las reglas procedimentales y competenciales han sido respetadas. Sobre la cuestión, véase Özbudun (1997: 18-19) y Özbudun y Turhan (1995: 21-26).

2 Sobre el conflicto laboral de los controladores, véase Vidal Prado y Delgado Ramos (2011: 243-247). 
Ante esta situación, el Gobierno decidió declarar el estado de alama mediante el Real Decreto 1673/2010, de 4 de diciembre, cuyo art. 3 atribuyó a los controladores la consideración de personal militar a los efectos de lo previsto en el art.10 LOAES, quedando sometidos a las leyes penales y disciplinarias militares. Debido a ello, la normalidad fue restablecida, pero, ante el riesgo de que la situación se reprodujera, el Gobierno solicitó al Congreso de los Diputados autorización para prorrogar el estado de alarma y, tras obtenerla, aprobó el Real Decreto 1717/2010, de 17 de diciembre, que prorrogó hasta las 00.00 horas del 15 de enero de 2011.

Los controladores consideraron que la declaración no se ajustaba a los supuestos previstos en el art. 4 LOAES, que la militarización era abusiva y que la prórroga no estaba justificada e interpusieron varios recursos contencioso-administrativo ante la Sala 3. ${ }^{a}$ del Tribunal Supremo (TS), lo que inició una larga guerra judicial en pos del control jurisdiccional de la declaración y de la prórroga del estado de alarma, que, hasta el momento, ha dado lugar a siete Autos del TS (AATS 857/2011, de 10 de febrero; 2985/2011, de 9 de marzo; 3816/2011, de 5 de abril; 5696/2011 y 5698/2011, de 30 de mayo; 6821/2011, de 8 de junio; y 6197/2012, de 1 de junio) que inadmitieron los recursos contencioso-administrativos; al Auto del Tribunal Constitucional (TC) 7/2012, de 13 de enero de 2012, que inadmitió el recurso de amparo contra el acuerdo del Pleno del Congreso de los Diputados de autorización de la prórroga y, finalmente, a la importante Sentencia del TC 83/2016, de 28 de abril, que ha desestimado el recurso de amparo contra el ATS 5696/2011 que negó la revisión jurisdiccional del decreto de declaración del estado de alarma, del acuerdo del Consejo de Ministros por el que se solicitaba al Congreso la autorización para prorrogarlo y del decreto de prórroga.

El Pleno del TC, que avocó para sí la resolución del último recurso de amparo, ha considerado que, más allá de las concretas vulneraciones de derechos, el problema suscitado - relativo a la fiscalización jurisdiccional de las decisiones de declaración y prórroga de los estados de excepción- es «una cuestión nuclear, novedosa y de indiscutible relevancia constitucional» que exige la determinación de la naturaleza jurídica de dichas decisiones «con la consiguiente delimitación en nuestro ordenamiento de los ámbitos propios de la jurisdicción ordinaria y de la propia jurisdicción constitucional» (fundamento jurídico 2. ${ }^{\circ}$ ). La STC 83/2016 afronta sistemáticamente el problema y procede a la caracterización jurídica de las decisiones de excepción en el marco del sistema de fuentes, con consecuencias importantes para el derecho constitucional de excepción y nuestro modelo de jurisdicción constitucional.

El objeto de este trabajo es estudiar las razones de dicha caracterización y valorar su alcance. A tal efecto, analizaré en primer lugar los elementos que 
material y formalmente suscitan dudas sobre las decisiones de excepción y su control jurisdiccional. En segundo lugar, sintetizaré las opiniones de la doctrina sobre la naturaleza de los decretos gubernamentales, las autorizaciones y las resoluciones parlamentarias de excepción, cuyas diferencias impedían, para la mayoría de los autores, que pudieran ser englobados en una misma categoría jurídica; y explicitaré las razones por las que algunos autores, no obstante, conceptuaron las diferentes decisiones excepcionales como actos con fuerza de ley. Seguidamente, identificaré los actos simples y complejos que conforman las decisiones de declaración y prórroga de los estados de excepción a efectos de su posible control jurisdiccional. Analizado el marco teórico, abordaré en sendos epígrafes los pronunciamientos contenidos en los AATS anteriormente citados, en el ATC 7/2012, de 13 de enero de 2012, y en la trascendental STC 83/2016, de 28 de abril, que, asumiendo la posición doctrinal que enmarcaba sistemáticamente las decisiones excepcionales en una misma categoría jurídica, caracteriza las decisiones de declaración y prórroga de los estados de excepción como actos con fuerza de ley solo susceptibles de control de constitucionalidad.

\section{DIVERSIDAD DE FORMAS DE DECLARACIÓN Y PRÓRROGA DE LOS ESTADOS EXCEPCIONALES Y AUSENCIA DE PREVISIÓN SOBRE SU CONTROL JURISDICCIONAL}

El derecho constitucional de excepción es el resultado de una tensa evolución que racionaliza el principio de necesidad y limita la acción del poder ejecutivo en la crisis. Con esa finalidad, el constitucionalismo liberal introdujo el principio de doble reserva de ley: la primera, para que el legislador estableciera de antemano el régimen jurídico de los estados excepcionales; la segunda, para que fuera el Parlamento, y no el Gobierno, quien apreciara la existencia de la emergencia y decidiera su declaración. Se distinguió, de este modo, entre titular y beneficiario de los poderes extraordinarios, asignándose estos roles al Parlamento y al Ejecutivo, respectivamente. Y se otorgó a la decisión de crisis rango de ley en sentido formal. Un rango que vino a formalizar la tendencia precedente en el derecho continental de excepción, en el que, desde la Revolución Francesa, se había reconocido materialmente «fuerza de ley» a los decretos parlamentarios que no llevaban el nombre de leyes, a los decretos gubernamentales de excepción y a los reglamentos de necesidad dictados por los monarcas centroeuropeos en situaciones críticas (Santamaría Pastor, 1988: 543-544; y Álvarez García, 1996: 91-100). 
El constituyente de 1869 incorporó el principio de doble reserva de ley a nuestro derecho de excepción y lo desglosó en dos momentos: ley-marco de orden público reguladora de los estados excepcionales y ley singular de suspensión de garantías, de forma que solo tras la aprobación de dicha ley singular sería aplicable la ley-marco. La Ley de Orden Público de 1870 mantuvo formalmente la reserva de ley para declarar la excepción, pero fue sistemáticamente incumplida proclamándose las emergencias durante décadas incluso mediante bandos militares ${ }^{3}$. Tras el franquismo, el constituyente de 1978 asumió de nuevo la exigencia de doble intervención del legislativo en el derecho de excepción, aunque introdujo singularidades significativas que han alterado la naturaleza jurídico-formal de la segunda intervención.

La regulación de los estados excepcionales precisa ley orgánica, siendo esta la primera intervención parlamentaria, que se materializó con la Ley Orgánica 4/1981, de 1 de junio, de los Estados de Alarma, Excepción y Sitio (LOAES). Suscitada una emergencia procede la segunda intervención, pero el art.116 CE no exige que revista naturaleza de ley formal y la intervención parlamentaria tiene diverso alcance según el estado. En el estado de sitio, el Congreso declara la emergencia por sí mismo mediante una resolución. En el estado de excepción y en la prórroga del estado de alarma, el Congreso autoriza la decisión, pero el Gobierno la formaliza. En el estado de alarma, la declaración compete al Gobierno y la intervención del Congreso se limita a recibir información.

No acaban ahí las singularidades. Las decisiones excepcionales previstas en el art. 116 CE proclaman la emergencia, pero también determinan el régimen jurídico del estado excepcional declarado, lo que las declaraciones de nuestra historia constitucional no hacían puesto que se limitaban a activar los preceptos de la ley general reguladora de los estados críticos. «[...] en nuestro sistema actual [subraya por ello Cruz Villalón (1981: 115)] la declaración —o, en su caso, autorización-declaración- del estado excepcional se configura como un tercer nivel normativo, que viene a sumarse a la LOAES y a la Constitución en el sistema de fuentes del derecho de excepción».

Materialmente, las decisiones excepcionales del art. $116 \mathrm{CE}$ son, por tanto, mitad actos mitad normas. En cuanto actos jurídicos, sirven para constatar y proclamar la emergencia. En cuanto normas, concretan el estatuto extraordinario del poder y constituyen fuente de habilitación de disposiciones y actos de ejecución del estado declarado. Formalmente, la singularidad de las

3 Sobre los avatares y suspensiones del principio de legalidad en el derecho español de excepción, véase Cruz Villalón (1980: 400-434) y Fernández Segado (1977: 100-129). 
decisiones excepcionales es mayor, pues proceden de órganos distintos, y distintos son tanto los procedimientos de adopción como su formalización jurídica, lo que hace dudoso caracterizarlas conforme a las categorías al uso.

Lo que no admite duda es que cualquiera de estas decisiones puede incidir sobre la normatividad constitucional y violarla. El Gobierno podría aprovechar la declaración del estado de alarma para limitar el ejercicio de derechos fundamentales. De no existir amenaza de sanción, también podría declarar el estado de excepción o prorrogar el estado de alarma imponiendo condiciones distintas a las parlamentariamente autorizadas. Y el Congreso de los Diputados también podría declarar el estado de sitio suspendiendo derechos que el art. 55.1 CE salvaguarda atentando contra las garantías institucionales previstas en el art. $116 \mathrm{CE}$.

La gravedad de estas hipótesis debería haber llevado al legislador a determinar con precisión las garantías jurisdiccionales existentes frente a las decisiones excepcionales. La CE, sin embargo, nada indicó al respecto. La LOTC podía haber incluido estas decisiones entre el elenco de normas y actos susceptibles de declaración de inconstitucionalidad contenido en su art. 27.2, pero no lo hizo. Al amparo del art. 161.1.d) CE, que permite conocer al TC «de las demás materias que le atribuyan la Constitución y las leyes», la LOAES podía haberle asignado la competencia para controlar la declaración y prórroga de estos estados, o remitirla a otro órgano, pero tampoco dio el paso. Y es esa ausencia de título competencial expreso para el control de estas decisiones, unida a su «borrosa» naturaleza jurídica ${ }^{4}$, lo que dificulta la atribución de la facultad de revisión a alguno de los órganos jurisdiccionales del Estado.

\section{POSICIONES DOCTRINALES SOBRE LA NATURALEZA JURÍDICA DE LAS DECISIONES EXCEPCIONALES Y SU CONTROL JURISDICCIONAL}

Debido a sus diferencias, la mayoría de la doctrina ha considerado que los decretos gubernamentales de declaración y prórroga de los estados de alarma y excepción no podían tener la misma naturaleza que las autorizaciones y resoluciones parlamentarias excepcionales. Y careciendo de naturaleza común, el control jurisdiccional de estas decisiones no podía ser idéntico, ni atribuirse al mismo órgano. Para una minoría de autores, más atentos al contenido y los efectos de las decisiones que a su forma, los decretos gubernamentales y los acuerdos parlamentarios tendrían, en cambio, la misma naturaleza jurídica; y su control correspondería, en todos los casos, a la jurisdicción

4 Sobre la idea de «realidad jurídica borrosa», véase Bastida Freijedo (1998: 381-394). 
constitucional. Sintetizando las opiniones al respecto, expondré en primer término la consideración diferenciada que en la doctrina han tenido los decretos gubernamentales y las autorizaciones y resoluciones parlamentarias de excepción y, seguidamente, las razones aducidas por quienes caracterizan todas estas decisiones bajo una misma categoría jurídica.

\section{LOS DECRETOS GUBERNAMENTALES DE EXCEPCIÓN: ¿ACTOS POLÍTICOS O DISPOSICIONES REGLAMENTARIAS?}

Tradicionalmente, ha existido en todos los ordenamientos jurídicos un último reducto de decisiones que, debido a su naturaleza política, escapaban al control jurisdiccional. Son los célebres actes de gouvernement de la jurisprudencia francesa y las political questions en terminología anglosajona; categorías utilizadas para justificar aquellas decisiones dirigidas a asegurar la supervivencia del Estado. Así las cosas, no resulta extraño que los decretos previstos en el art. $116 \mathrm{CE}$ para poner en marcha los poderes excepcionales hayan sido caracterizados por alguna doctrina como actos políticos o de Gobierno ajenos al derecho administrativo y exentos, en virtud del principio de separación de poderes, de todo control jurisdiccional. En tanto actos del Gobierno carentes de valor de ley, su control no podía ser residenciado ante el TC. Y al adoptarse bajo una habilitación constitucional expresa, tampoco serían susceptibles de revisión contencioso-administrativas.

Para otra doctrina (Mateu-Ros, 1988: 193-195; y López Guerra, 1988: 26), la naturaleza política de estas decisiones excepcionales no era óbice, sin embargo, para controlar sus elementos reglados y su respeto a los derechos fundamentales a través del recurso de amparo ante el TC. Así lo subrayó, aunque sin referirse concretamente a estas decisiones, el propio Tribunal en las SSTC 196/1990, de 29 de noviembre, y 220/1991, de 25 de noviembre, donde, tras reconocer la existencia de actos del Gobierno no sujetos al derecho administrativo y, por ello, exentos de control contencioso-administrativo, proclamó su sujeción a la Constitución, así como la posibilidad de que dichos actos sean recurridos directamente en amparo al no existir tribunal ordinario competente para tutelarlos con anterioridad, en cuyo caso el TC tendría competencia para su revisión a semejanza de lo establecido en el art. 42 LOTC para los actos parlamentarios sin valor de ley.

5 En este sentido, véase Fernández Segado (1981: 98-99) y Serrano Alberca (1979: 1969-1971; y 2001: 1787-1788). 
Pese a esta doctrina del TC, varios pronunciamientos del TS admitieron la fiscalización contencioso-administrativa de los actos de dirección política en lo relativo a «las eventuales extralimitaciones o incumplimientos de los requisitos reglados en que el Gobierno hubiera podido incurrir al tomar la decisión» (SSTS de 28 de junio de 1994 y 4 de abril de 1997). Y, siguiendo su estela, el legislador quiso dar «jaque mate» a la doctrina del acto político en el derecho español mediante la Ley 29/1998, de 13 de julio, reguladora de la Jurisdicción Contencioso-administrativa (LJCA), cuyo art. 2.a) somete a esta jurisdicción «los actos y disposiciones del Gobierno o de los Consejos de Gobierno de las Comunidades Autónomas, cualquiera que fuere la naturaleza de dichos actos», por lo que atañe a la protección de los derechos fundamentales, a los elementos reglados del acto y a la determinación de la posible indemnización ${ }^{6}$. Consecuentemente, las opiniones doctrinales que consideraron los decretos gubernamentales de excepción actos políticos exentos de control por la jurisdicción ordinaria han quedado superadas, pues la Sala 3.a del TS podría revisar sus elementos reglados y su compatibilidad con los derechos fundamentales.

Para otra doctrina, los decretos gubernamentales de declaración y prórroga de la excepción serían, atendiendo a su formalización jurídica, disposiciones reglamentarias susceptibles de control de legalidad al amparo del art. 106 CE. Justiciables serían, en opinión de Rodríguez Oliver (1981: 2316), el decreto de declaración del estado de alarma, pero también los decretos de prórroga del estado de alarma y de declaración y prórroga del estado de excepción autorizados por el Congreso en la medida en que no se ajustaran a las autorizaciones parlamentarias correspondientes, porque al excederse en su formalización reglada recuperarían su simple naturaleza reglamentaria. En el mismo sentido se pronunciaron Cruz Villalón (1981: 115-116) y Lafuente Balle (1990: 34 y 42), para quienes, aunque los decretos de prórroga del estado de alarma y de declaración y prórroga del estado de excepción son comparables, en su relación con la autorización parlamentaria, con los decretos legislativos en su relación con delegación legislativa, no pueden considerarse, a diferencia de estos, disposiciones normativas con rango de ley. El decreto gubernamental «es poco más que un requisito formal» de la entrada en vigor o de la prórroga del estado excepcional y, como norma que formaliza hacia el exterior la declaración, «es susceptible de control jurisdiccional, control de legalidad que operará respecto de la LOAES, tanto directamente como indirectamente, por

6 La expresión «jaque mate» referida a la doctrina del acto político fue usada por Jordano Fraga (1997: 417-446). Sobre el alcance del art. 2.a) LJCA, véase Gómez Montoro (2005: 477-502). 
violación de la autorización del Congreso». Y en la misma línea se ha expresado Requejo Rodríguez (2012: 1512-1513) con ocasión del estado de alarma declarado el 4 de diciembre de 2010, para quien la naturaleza jurídica de la declaración y la prórroga gubernamentales son la de reglamento, sin que la intervención del Congreso, recibiendo primero una mera comunicación del Gobierno o autorizando después la prórroga, suponga una elevación del rango de la norma que formaliza tanto la declaración como la prórroga, razón por la cual su control debía recaer en la jurisdicción contencioso-administrativa.

\section{LAS AUTORIZACIONES Y RESOLUCIONES PARLAMENTARIAS DE DECLARACIÓN Y PRÓRROGA DE LOS ESTADOS EXCEPCIONALES: ACTOS PARLAMENTARIOS CON O SIN VALOR DE LEY}

Distinta consideración jurídica han tenido las autorizaciones parlamentarias de prórroga del estado de alarma y de declaración y prórroga del estado de excepción, así como las resoluciones parlamentarias de declaración y prórroga del estado de sitio.

Mateu-Ros (1988: 1400-1401) ha sostenido que la declaración del estado de sitio, concretamente, tiene la naturaleza de una ley ad hoc dictada en ejercicio de una función normativa material que no persigue crear un orden con vocación de permanencia, sino afrontar un problema concreto determinado espacial y temporalmente. Se trataría de una «ley-medida» (Massnabmegesetz), una noción elaborada por Schmitt (1982: 110-118) en el período de entreguerras para aludir a una serie de decisiones normativas con fuerza de ley adoptadas por el presidente del Reich de acuerdo con el art. 48.2 de la Constitución de Weimar. Por su parte, Cruz Villalón (1981: 115; y 1984: 140) ha caracterizado la declaración del estado de sitio como una disposición normativa con rango de ley, al hallarse «en una situación muy aproximada a la de un decreto-ley a partir del momento de su convalidación», pudiendo, por ello, ser objeto de recurso y de cuestión de inconstitucionalidad. Serrano Alberca (2001: 1791 y 1801) comparte la opinión de ambos autores sobre la declaración y prórroga del estado de sitio. Pero respecto de la autorización para declarar y prorrogar el estado de excepción o prorrogar el de alarma, ha sostenido que su naturaleza es similar a la delegación legislativa, con las diferencias de la intervención de una sola Cámara y de que el decreto de declaración debe ser, prácticamente, una trascripción de la autorización del Congreso. Optando, en fin, por un criterio material, Navas Castillo (1997: 155) ha afirmado que tanto la resolución declaratoria del estado de sitio como las autorizaciones del estado de excepción o de prórroga del estado de alarma pueden incluirse dentro de la 
categoría de las disposiciones normativas con rango de ley en la medida en que disponen la normativa aplicable durante el estado declarado y constituyen fuente y habilitación de disposiciones y actos de ejecución, por lo que serían susceptibles de control de constitucionalidad.

Otra doctrina, por el contrario, ha considerado la declaración y la prórroga del estado de sitio y las autorizaciones para declarar y prorrogar el estado de excepción y prorrogar el estado de alarma como simples actos parlamentarios sin fuerza de ley, resistentes a la jurisdicción ordinaria debido a la autonomía parlamentaria y exentos, por naturaleza, de control de constitucionalidad (Fernández Segado, 1981: 113; y Alonso Más, 1999: 148-150). En el supuesto de alcanzar eficacia jurídica externa, tan solo serían impugnables ante el TC mediante un recurso de amparo ex art. 42 LOTC y, si hubiera lugar, mediante un conflicto de atribuciones entre órganos constitucionales o de competencias entre el Estado y las comunidades autónomas (CC. AA.).

Para otros autores (Cruz Villalón, 1981: 114-115 y 1984: 140; Punset Blanco, 2001: 381-382; y Aragón Reyes, 2001: 181-183), las referidas decisiones parlamentarias críticas, o al menos alguna de ellas, deben ser, en cambio, caracterizadas como "actos del Estado con fuerza de ley», categoría reconocida en el art. 27.2.b) LOTC como objeto susceptible de control de constitucionalidad a fin de reducir un buen número de situaciones de inmunidad jurisdiccional que hubieran cuestionado la vigencia del Estado de derecho. Dada la indeterminación de la expresión "actos con fuerza de ley», quienes secundan esta tesis han considerado dotados de esta fuerza tan solo los actos jurídico-públicos de incidencia normativa — aunque esta sea transitoria- en los que el Parlamento o una de sus Cámaras interviene en su procedimiento de adopción. La fuerza de ley sería, así, una cualidad de ciertos actos derivada de la intervención parlamentaria. En opinión de Punset Blanco (2001: 412), este sería el caso exclusivamente de la declaración y prórroga del estado de sitio. Para Cruz Villalón (1984: 140), que defiende la naturaleza de disposición normativa con rango de ley de la declaración y prórroga del estado de sitio, los actos del Estado con fuerza de ley serían, en cambio, las autorizaciones para declarar y prorrogar el estado de excepción y prorrogar el de alarma. Aragón reyes (2001: 342) sostiene, por su parte, que tanto las autorizaciones de declaración y prórroga en los estados de excepción y alarma como las resoluciones parlamentarias en el estado de sitio pertenecen a dicha categoría, pues ambas, independientemente de su materialización mediante acuerdo o resolución, constituyen una expresión de la voluntad 
parlamentaria, siendo esta cualidad la que determina su naturaleza jurídica y les otorga fuerza de ley?

\section{LAS DECISIONES DE DECLARACIÓN Y PRÓRROGA DE LOS ESTADOS DE ALARMA, EXCEPCIÓN Y SITIO COMO ACTOS DEL ESTADO CON FUERZA DE LEY}

Para una minoría de autores (Porres Azcona, 1983: 47; García Cuadrado, 1999a: 44-49 y 1999b: 283-286; y Garrido López, 2007: 133-139 y 2008: 1248-1251), los decretos gubernamentales y las decisiones parlamentarias de declaración y prórroga de los estados excepcionales tendrían, pese a proceder de órganos distintos, una idéntica naturaleza jurídica. Según esta posición sistemática, todas estas decisiones - $\mathrm{y}$ no solo las de origen parlamentario- pueden ser caracterizadas como actos con fuerza de ley. Dicha fuerza tendría que ver con la condición de complemento imprescindible para la plena efectividad de ciertos preceptos constitucionales o para la validez de normas jurídicas con rango de ley que caracteriza a algunos actos, independientemente de su procedencia parlamentaria y del carácter simple o complejo del procedimiento establecido para su adopción. Los actos con fuerza de ley serían, de este modo, todos aquellos directamente incardinados en la CE, aquellos que la realizan o desarrollan, una razón por la que no cabe someterlos a control de legalidad, sino de constitucionalidad. Las decisiones de declaración y prórroga de los estados de alarma, excepción y sitio - que complementan los arts. 55.1 y $116 \mathrm{CE}$ y la propia LOAES - pertenecerían, claramente, a esta categoría por las siguientes razones.

El triunfo de la noción formal sobre la noción material de ley supuso la consagración del principio de supremacía parlamentaria, en virtud del cual las más importantes decisiones políticas quedaron reservadas al legislador. Pero la redefinición del papel del Estado, el reforzamiento de los ejecutivos y la racionalización de parlamentarismo trajeron consigo un cambio de paradigma que incidió sobre el régimen de prevalencia de la ley.

En la actualidad, la mayoría de las decisiones jurídico-políticas importantes siguen precisando forma de ley, pero junto con estas existen otras decisiones igualmente relevantes que, por no contener propiamente normas, son adoptadas por las Cámaras bajo la forma de acuerdos o resoluciones, o incluso por el Gobierno. Y no por ello pierden la fuerza de las decisiones legislativas.

En este sentido, véase también Navas Castillo (2000: 46-50), quien ha asumido esta tesis matizando su opinión inicial anteriormente mencionada. 
Al contrario, son actos con fuerza de ley, lo que no quiere decir que puedan derogar leyes formales - cosa que no pueden hacer hoy muchas leyes respecto de otras determinadas-, sino que tienen el mismo valor y el mismo rango que las leyes ${ }^{8}$. No en vano, dichos actos aplican directamente un precepto constitucional o constituyen complemento necesario para su aplicación. Son, por ello, actos primarios, como aquellas son normas primarias. Pero a diferencia de las leyes, que pueden tener cualquier contenido, estos actos dotados de fuerza de ley siempre versan sobre materia constitucional.

Estas decisiones no son propiamente normas porque no contienen mandatos generales y abstractos que se incorporen establemente al ordenamiento jurídico. Tampoco son actos administrativos porque ni su contenido ni la competencia de su titular están legalmente reglados, sino constitucionalmente reglados. Son actos con valor de ley porque representan la aplicación a un supuesto concreto de la propia CE (García Cuadrado, 1999a: 93-97 y 1999b: 281-282). Y ello, sin perjuicio de que en ocasiones la normatividad constitucional haya debido ser completada por una norma legal a la que aquella se remitía y que, por esa razón, se convierte también en canon o parámetro de referencia para el correspondiente juicio de constitucionalidad.

Dogmáticamente definidos por su carácter primario y su incidencia constitucional o, al menos, legislativa, lo cierto es que la identificación de los actos del Estado con fuerza de ley entre las diversos actos jurídico-públicos que pueblan el ordenamiento jurídico no resulta del todo pacífica. La diferencia acto-norma es clara en el nivel administrativo, pero resulta más borrosa si nos elevamos al nivel constitucional, cuando de lo que se trata es de dilucidar la naturaleza jurídica de los decretos de disolución de las Cámaras, de los decretos de coerción estatal, de la declaración gubernamental o parlamentaria de los estados excepcionales o de los nombramientos de las primeras

$8 \quad$ En palabras de Kelsen (1988: 116-117), «es posible que la Constitución se concrete por medio de formas jurídicas distintas de las leyes, en particular por medio de reglamentos de necesidad o incluso por medio de actos jurídicos individuales. [...] La Constitución puede, por ejemplo, disponer que, en condiciones perfectamente determinadas, puedan ser dictadas normas generales no mediante el voto parlamentario, sino mediante un acto del gobierno; se trata entonces de los reglamentos de necesidad, que tienen el mismo grado y fuerza que las leyes. [...] Y nada se opone tampoco a la existencia de normas constitucionales que sean ellas mismas aplicables a los casos concretos por medio de actos individuales. Siendo así las cosas, hay no solamente normas generales - leyes y reglamentos—, sino también actos que están inmediatamente subordinados a la Constitución y que pueden ser, por consiguiente, inmediatamente inconstitucionales». 
autoridades del Estado, entre otros. De ahí que la doctrina discrepe a la hora de atribuir fuerza de ley a ciertas decisiones directamente infraordenadas a nuestra CE.

Para alguna doctrina, esta sería una cualidad solo predicable de los actos de incidencia constitucional en los que el Parlamento o una de sus Cámaras interviene en su procedimiento de adopción, lo que excluiría de la categoría a los decretos exclusivamente gubernamentales, como el de declaración del estado de alarma (Cruz Villalón, 1984: 140; Navas Castillo, 2000: 46-50; y Aragón Reyes, 2001: 342). Para quienes hemos defendido la interpretación sistemática de la categoría, por el contrario, tienen fuerza de ley aquellos actos que, intervenga o no el Parlamento en su emanación, realizan preceptos constitucionales o son necesarios para la validez de normas con rango de ley. De ahí que, no obstante los instrumentos formales utilizados para adoptarlos, somos de la opinión de que tanto los decretos gubernamentales como las resoluciones parlamentarias de declaración y prórroga de los estados excepcionales pueden considerarse actos con fuerza de ley (García Cuadrado, 1999a: 44-49 y 1999b: 283-286; y Garrido López, 2007: 138-139 y 2008: 1248-1251).

Las declaraciones y prórrogas de los estados de alarma, excepción y sitio son actos dictados al amparo de los arts. 55.1 y 116 de la CE. Son decisiones singulares y concretas directamente infraordenadas a la $\mathrm{CE}$, cuyas previsiones, debido a las reservas expresas establecidas por el constituyente, han sido completadas - en lo que se refiere a las competencias y limitaciones de los estados excepcionales - por la LOAES. No dejan, por ello, de tener fuerza de ley. El parámetro o canon de enjuiciamiento de su constitucionalidad se habrá ampliado con esta norma interpuesta, pero esa ampliación no afecta a la naturaleza de dichos actos, ni convierte su control jurisdiccional en control de legalidad. Son, por ello, a juicio de la doctrina citada, actos con fuerza ley directamente incardinados en la CE solo susceptibles de control de constitucionalidad.

\section{CARACTERIZACIÓN DE LOS DIVERSOS ACTOS QUE CONFORMAN LAS DECISIONES DE DECLARACIÓN Y PRÓRROGA DE LOS ESTADOS DE EXCEPCIÓN A EFECTOS DEL ART. 27.2.B) LOTC}

La declaración del estado de alarma es un acto simple formalizado mediante decreto. Las declaraciones y eventuales prórrogas de los estados de excepción y sitio y la prórroga del estado de alarma son actos compuestos de diversos actos simples, tales como la solicitud gubernamental, la autorización parlamentaria y el real decreto, en los casos de declaración y prórroga del estado de excepción y de prórroga del estado de alarma, o la propuesta 
gubernamental y la resolución parlamentaria, en los supuestos de declaración y prórroga del estado de sitio.

En opinión de alguna doctrina, los actos simples necesarios para la emisión del acto complejo también tendrían la consideración de actos con fuerza de ley. Según esta interpretación, por ejemplo, la solicitud del Gobierno al Congreso para que lo autorice a declarar el estado de excepción, el acuerdo parlamentario de autorización y el real decreto declarándolo serían actos de la misma naturaleza9. Y, consecuentemente, serían susceptibles de control de constitucionalidad. No creo, sin embargo, que ello sea así.

Sin duda, los actos simples que integran un acto constitucional compuesto trascienden la legalidad "para incidir en el orden constitucional», como señaló la STC 16/1984, de 14 de febrero, al pronunciarse sobre el acto simple de propuesta de nombramiento de presidente de la Comunidad Foral de Navarra por el Parlamento de dicha comunidad, al que habían de seguirle el nombramiento por el rey y el refrendo del presidente del Gobierno ${ }^{10}$. Las solicitudes gubernamentales y las autorizaciones parlamentarias para declarar y prorrogar un estado excepcional están directamente incardinadas en la CE y versan sobre materia constitucional. Estos actos simples, sin embargo, no pueden tener fuerza de ley porque carecen de eficacia jurídica externa. Son actos resolutorios y firmes. Y son relevantes para el derecho en la medida en que determinan el contenido del decreto de declaración o de prórroga, como ocurre con las autorizaciones parlamentarias, pero no activan por sí mismos la constitución alternativa de emergencia. No constituyen un complemento necesario de precepto constitucional alguno, ni enervan el estatuto ordinario de los derechos fundamentales. Son actos-parte o actos parciales (teilakt, en terminología germana) carentes de efectividad ad extra al margen del procedimiento complejo de adopción de los actos compuestos de declaración y prórroga de los estados excepcionales.

9 García Cuadrado (1999a: 63). De similar opinión, Porres Azkona (1983: 47-48); Cruz Villalón (1981: 140); Aragón Reyes (2001: 342), y Navas Castillo (2000: 205), quienes también atribuyen a las autorizaciones parlamentarias la naturaleza de actos con fuerza de ley, aunque, a diferencia de García Cuadrado, no estiman que las propuestas gubernamentales de autorización, en el caso de declaración y prórroga del estado de excepción y prórroga del estado de alarma, o la solicitud gubernamental, en el caso del estado de sitio, tengan esa naturaleza.

10 Dicho nombramiento es «un acto compuesto [...] el cual comprende cada uno de los que lo forman" $\mathrm{y}$ "ha de incluirse en su conjunto y en cada una de sus partes dentro de la materia constitucional» (STC 16/1984, fundamento jurídico 4.o ). 
Así lo reconoció mutatis mutandis el TC en relación con el acto simple de propuesta de nombramiento de presidente de la Comunidad Foral de Navarra impugnado, para quien, pese a culminar el procedimiento en la comunidad y ser resolutorio, «dada la naturaleza del acto compuesto que tiene el nombramiento, la decisión de la Comunidad pasa a integrarse en tal acto del que forma parte» (STC 16/1984, fundamento jurídico 4.o). Y así lo ha reconocido también al rechazar en este caso la impugnación del acuerdo del Gobierno Vasco de 25 de octubre de 2003, por el que se aprobó una denominada Propuesta de Estatuto Político de la Comunidad de Euskadi, y del acuerdo de la Mesa del citado Parlamento de 4 de noviembre de 2003, por el que se admitió a trámite la propuesta de reforma del Estatuto, para su tramitación conforme al procedimiento legislativo ordinario. En el ATC 135/2004, de 20 de abril (fundamentos jurídicos $6 .^{\circ}$ y $7^{\circ}$ ), se afirma que ambos actos forman parte, como «secuencias consecutivas», de un mismo procedimiento legislativo y que no producen más efecto jurídico que el puramente ad intra ligado a su subsiguiente tramitación. Su eventual inconstitucionalidad, en suma, solo sería relevante cuando su contenido se plasme en el acto complejo con eficacia ad extra que pusiera fin al procedimiento de reforma estatutaria.

En el caso que nos ocupa, consecuentemente, solo los actos compuestos de declaración y prórroga de los estados excepcionales están dotados de una eficacia jurídica externa, erga omnes, y directa, no la solicitud gubernamental ni la autorización parlamentaria previas a su adopción. Solo dichos actos de declaración y prórroga — conformados por todas y cada una de las voluntades requeridas formuladas mediante actos simples y debidamente formalizadospueden tener fuerza de ley. Infraordenados inmediatamente a la CE (arts. 55.1 y 116), solo la declaración y prórroga tienen incidencia constitucional en cuanto a la distribución del poder y al sistema de garantías, por lo que solo dichos actos, y no los actos parte que los integran, deberían ser objeto de control de constitucionalidad.

\section{LOS AUTOS DEL TRIBUNAL SUPREMO SOBRE LOS DECRETOS DE DECLARACIÓN Y PRÓRROGA DEL ESTADO DE ALARMA DE DICIEMBRE DE 2010: LA AUTORIZACIÓN PARLAMENTARIA DE LA PRÓRROGA COMO INSÓLITA CAUSA EX POST FACTO DE EXCLUSIÓN DEL CONTROL JURISDICCIONAL DE SU DECLARACIÓN}

El abandono de los controladores aéreos de sus puestos durante la tarde de 3 diciembre de 2010 desencadenó el cierre del espacio aéreo español y el colapso aeroportuario. Estas circunstancias extraordinarias, que no cedieron 
tras la atribución al jefe del Estado Mayor del Ejército del Aire de las facultades absolutas laborales sobre los controladores civiles al amparo del art. 4.4.a) de la Ley 21/2003, de 7 de julio, de Seguridad Aérea, y de la disposición adicional primera de la Ley 9/2010, de 14 de abril, por la que se regula la Prestación de Servicios de Tránsito Aéreo, llevaron al Gobierno de la nación a declarar, mediante el Real Decreto 1673/2010, de 4 de diciembre [BOE núm. 295, de 4 de diciembre (extraordinario)], el estado de alarma previsto en el art. $116 \mathrm{CE}$ al amparo del art. 4.c), en relación con los apartados a) y d) LOAES, incluyendo en su ámbito personal de aplicación a todos los controladores al servicio de AENA, que pasaron a tener la consideración de personal militar y quedaron sometidos a las autoridades militares y a las leyes penales y disciplinarias militares, de conformidad con el art. 8 de la Ley Orgánica 13/1985, de 9 de diciembre, Penal Militar.

Ante el riesgo de que la situación se reprodujera días después, el Consejo de Ministros solicitó del Congreso de los Diputados la pertinente autorización para prorrogarlo. Y autorizado mediante acuerdo del Pleno de 16 de diciembre, el Gobierno prorrogó el estado de alarma mediante el Real Decreto 1717/2010, de 17 de diciembre (BOE núm. 307, de 18 de diciembre) hasta las 00.00 horas del día 16 de enero de 2011 con las mismas condiciones establecidas en su declaración.

La Unión Sindical de Controladores Aéreos (USCA) interpuso sendos recursos contencioso-contenciosos contra el real decreto de declaración del estado de alama y el real decreto de prórroga. Días después, varios controladores aéreos interpusieron un nuevo recurso contra el real decreto de declaración. Y en régimen de litisconsorcio activo necesario, varios cientos de controladores interpusieron un cuarto recurso, en esta ocasión contra el decreto de declaración, el acuerdo del Consejo de Ministros en el que se decidió solicitar al Congreso autorización para prorrogar el estado de alarma y el Decreto que lo prorrogó.

Los recursos se basaban en cuatro argumentos: (i) el estado de alarma era ilegal porque la paralización de servicios públicos esenciales citada en el art. 4.c) LOAES entre las emergencias que justifican su declaración no constituye un supuesto autónomo que habilita la declaración si no concurre simultáneamente algún otro supuesto de los previstos en las letras a), b) y d) del mismo precepto; (ii) la designación como autoridad delegada del jefe del Estado Mayor del Ejército del Aire era ilegal; (iii) la militarización de los controladores implicó la vulneración de sus derechos fundamentales y conculcó el art. 117.5 CE, que limita la jurisdicción militar al ámbito estrictamente 
castrense y al estado de $\operatorname{sitio}^{11}$, y (iv) la prórroga fue improcedente porque la incertidumbre o el mero riesgo de reproducción de la emergencia no la justifica. En opinión de los recurrentes, la declaración y la prórroga del estado de alarma son disposiciones reglamentarias del Gobierno y, por ello, debían ser fiscalizadas por la jurisdicción contencioso-administrativa [arts. 12.1.a) LJCA y 3.1 LOAES]. Pero es que, aun cuando se considerasen actos políticos, no estarían exentos de control por esa jurisdicción, al menos por lo que respecta a sus elementos reglados y al respeto de los derechos fundamentales [art. 2.1.a) LJCA].

Pese a los argumentos aducidos, los recursos fueron inadmitidos en los AATS 857/2011, de 10 de febrero, y 2985/2011, de 9 de marzo (dictado tras recurso de súplica), AATS 3816/2011, de 5 de abril, y 6821/2011, de 8 de junio (también tras recurso de súplica), y los AATS 5696/2011 y 5698/2011, de 30 de mayo, el primero de los cuales fue confirmado en reposición por el ATS 6197/2012, de 1 de junio de 2012.

En estos pronunciamientos, el TS subrayó la doble condición del Gobierno como un órgano que ejerce la potestad reglamentaria y dirige la Administración General del Estado y como un órgano constitucional que desempeña funciones de dirección política reguladas directamente por la CE. En esta segunda condición, y no en la primera, el Gobierno decidió declarar el estado de alarma y su decisión fue comunicada al Congreso de los Diputados. Consciente, no obstante, el TS de que incluso los actos del Gobierno en relación con las Cortes regulados en el título V CE — como caracteriza la decisión crítica- no quedan exentos de control por parte de la jurisdicción contencioso-administrativa en virtud del art. 2.1.a) LJCA, recurrió a un insólito argumento para excluir su control. El TS afirmó que la impugnación iba dirigida contra un acto cuyo contenido había sido asumido en su integridad

11 En el mismo sentido, véase Vidal Prado y Delgado Ramos (2011: 255-260) y Requejo Rodríguez (2012: 1505-1506). Otros autores, en cambio, han defendido la constitucionalidad y legalidad de la medida, argumentando que ( $i)$ el art. 4 del Código Penal militar prevé la sujeción a la jurisdicción militar no solo de los militares, sino también del personal movilizado o a quien un precepto legal (o un acto con fuerza de ley) asimile; (ii) el art. 8.5 del Código Penal militar declara que son militares «los que con cualquier asimilación militar presten servicio al ser movilizados o militarizados a decisión del Gobierno»; y (iii) el art. 117.5 CE no determina el ámbito estrictamente castrense en el que actúa la jurisdicción militar, sino que se limita a señalar que dicho ámbito será determinado por la ley, lo que otorga cierta flexibilidad para concretar mediante ley —o acto con fuerza de ley- el alcance de ese ámbito (Jiménez Villarejo, 2010; y Aba Catoira, 2011: 338). 
por el Congreso de los Diputados desde el momento en que este autorizó la prórroga del estado de alarma en los mismos términos en que inicialmente fue declarado «y, por esta razón, esa decisión asumida por la Cámara no es una actuación que pueda ser controlada por este orden contencioso-administrativo» (ATS 857/2011, fundamento jurídico 4. ${ }^{\circ}$ ).

En su recurso de reposición, el sindicato USCA adujo que la autorización del Congreso no lo fue para la declaración del estado de alarma, sino para la prórroga, y que esa autorización no constituye una convalidación de la declaración recurrida, pero el TS, en el fundamento jurídico 3. ${ }^{\circ}$ del ATS 2985/2011, que fue reproducido en sus demás autos, abundó en la idea anterior y afirmó que la autorización de la prórroga en los mismos términos que el estado declarado es una verdadera convalidación de la declaración inicial, porque ratificó su validez y dispuso su continuidad. El Congreso, al autorizar la prórroga, «lo que hizo fue asumir como decisión propia esa inicial declaración y, por tanto, le dio naturaleza y carácter parlamentario. Es claro, pues, que no se está ya ante una actuación del Gobierno sino ante una resolución de la Cámara ejercitando una de las funciones que la Constitución le atribuye, como también lo es que esta resolución, está fuera [...] del concreto ámbito de conocimiento de la jurisdicción contencioso-administrativa que delimitan los arts. 1 y 2 LJCA».

Por idéntico motivo, el acuerdo del Consejo de Ministros que solicitaba la prórroga queda exento de control; y los mismos argumentos — que «cobran todavía más fuerza en este caso», según el ATS 3816/2011 — se aducen para considerar «parlamentarizada la decisión gubernamental» de prórroga, porque «aquí a la asunción por la Cámara del contenido de la declaración, con lo que esto implica de aceptación de su necesidad y regularidad, ha de añadirse que la prórroga no es constitucionalmente posible sin dicha autorización».

Estos argumentos usados para excluir de la jurisdicción ordinaria a las decisiones gubernamentales de excepción resultan, sin embargo, cuestionables. Según el TS, la autorización parlamentaria de la prórroga hace que la declaración gubernamental del estado de alarma cambie de naturaleza jurídica, pasando de acto de Gobierno a acto parlamentario exento de control jurisdiccional. Y lo mismo señala respecto del decreto de prórroga y del acuerdo de solicitud de esta. Pero ello no es posible jurídicamente. La declaración del estado de alarma no altera su naturaleza ni se parlamentariza ex post facto porque el Gobierno solicite y obtenga autorización para prorrogarlo. La autorización del Congreso no se concede para la declaración, que compete en exclusiva al Gobierno, sino para su prórroga. La autorización parlamentaria de la prórroga, por tanto, no «ratifica la validez» de la declaración, porque, si así fuera, ¿su denegación significaría que la declaración inicial ha sido 
inválida? Evidentemente, no: ni sería inválida, ni perdería por ello su eficacia. El TS eleva de rango la declaración del estado de alarma si ha sido autorizada su prórroga, pero no se plantea qué naturaleza tendría esa misma declaración si el Gobierno no solicita la prórroga al Congreso por no ser preciso, o si, pese a solicitarla, este decide denegarla. A tenor de su razonamiento, estaríamos, en estos casos, ante una declaración de distinta naturaleza porque no habría sino «parlamentarizada» posteriormente y, por lo tanto, dicha declaración sí podría ser sometida a control de la jurisdicción contencioso-administrativa. Ello sería contrario a la lógica jurídica, porque la naturaleza jurídica de los decretos gubernamentales de declaración de un estado de alarma no puede mutar en función de la existencia o no de autorización posterior de su prórroga. Su naturaleza depende de sí mismos, de su contenido y efectos, no de una supuesta convalidación lograda en un eventual procedimiento de prórroga.

\section{EL ATC 7/2012, DE 13 DE ENERO, SOBRE EL ACUERDO PARLAMENTARIO DE AUTORIZACIÓN DE LA PRÓRROGA DEL ESTADO DE ALARMA Y SU CONSIDERACIÓN COMO ACTO DOTADO DE EFICACIA JURÍDICA AD EXTRA CON FUERZA DE LEY}

Dada la importancia atribuida por el TS a la autorización parlamentaria de la prórroga del estado de alarma, 322 controladores aéreos decidieron interponer contra el acuerdo del Pleno del Congreso de los Diputados de 16 de diciembre de 2010 un recurso de amparo por vulneración de derechos fundamentales por la vía del art. 42 LOTC, considerando que dicho acuerdo era una decisión parlamentaria desprovista de fuerza de ley cuyo alcance va más allá de un trámite, puesto que, al habilitar al Gobierno a prolongar el estado declarado, posee efectos jurídicos externos y viola per se derechos fundamentales. Los propios AATS le otorgaban implícitamente esos efectos, al considerar que la autorización convalidaba la declaración y extendía su naturaleza parlamentaria a esta, que dejaba de ser un acto de Gobierno por su mera existencia.

Para el Pleno del TC, que avocó para sí el conocimiento del recurso, el acuerdo del Congreso de autorización de la prórroga no es, sin embargo, subsumible en la categoría de decisiones o actos sin valor de ley recurribles en amparo, sino en la de actos con fuerza o valor de ley. Con las expresiones «fuerza» o «valor» de ley, afirma el TC:

[...] la Constitución primero, y luego la LOTC, han querido acotar un genus de normas, decisiones y actos, del que serían especificaciones, además de la propia 
ley parlamentaria, otras fuentes en parte equiparadas a la misma por la propia Constitución, así como algunos actos, decisiones o resoluciones no identificados como tales ni en la Constitución ni en la LOTC, pero que sí gozarían de aquel "valor» o «rango», en virtud del cual no serían residenciables ante el Tribunal Constitucional por la vía del recurso de amparo» (fundamento jurídico 3.º).

Este sería el caso, a juicio del TC, de las autorizaciones parlamentarias para prorrogar el estado de alarma y para declarar o prorrogar el de excepción, así como de la declaración y prórroga por la propia Cámara del estado de sitio. Dichas decisiones parlamentarias no adoptan la forma de ley, pero configuran el régimen jurídico del estado de emergencia en cada caso y suponen «excepciones o modificaciones pro tempore en la aplicabilidad de determinadas normas del ordenamiento vigente, incluidas [...] disposiciones legales, que sin ser derogadas o modificadas sí pueden ver alterada su aplicabilidad ordinaria» (fundamento jurídico $4 .^{\circ}$ ).

Y aunque el acto de autorización parlamentaria de la prórroga del estado de alarma o el de autorización de la declaración y prórroga del de excepción puedan parecer actos autorizatorios de trámite carentes de eficacia externa, tienen, para el TC, un contenido normativo o regulador, puesto que fijan directamente el alcance, las condiciones y los términos a los que deben ajustarse la prórroga del estado de alarma o la declaración y prórroga del de excepción decretados por el Gobierno. Razón por la que, junto con las resoluciones parlamentarias de declaración y prórroga del estado de sitio, todos estos actos poseerían un rango o valor de ley en cuanto expresiones del ejercicio de una competencia constitucionalmente confiada a la Cámara Baja ex art. $116 \mathrm{CE}$. Y dada su naturaleza jurídica, el cauce para residenciarlos ante la jurisdicción constitucional no es el recurso de amparo del art. 42 LOTC, sino el de inconstitucionalidad, con la legitimación que le es propia, o, en su caso, la cuestión de inconstitucionalidad.

En la medida en que la declaración y prórroga del estado de sitio corresponden al Congreso, el ATC acierta al atribuir a las resoluciones parlamentarias en que se adoptan estas decisiones eficacia jurídica externa y fuerza de ley, pero no lo hace, en cambio, en nuestra opinión, al atribuir idéntica eficacia jurídica externa y fuerza de ley a las autorizaciones parlamentarias de prórroga del estado de alarma y de declaración y prórroga del estado de excepción. Como he señalado supra, las autorizaciones parlamentarias son presupuestos necesarios para la declaración y prórroga de estos estados, pero no sustituyen, ni pueden reemplazar, la declaración o prórroga gubernamental. Las autorizaciones parlamentarias forman parte esencial del procedimiento, pero son las decisiones gubernamentales de declaración y prórroga, formalizadas y 
exteriorizadas mediante decreto, las que tienen eficacia jurídica ad extra, no las autorizaciones. Solo las decisiones de declaración y prórroga fijan el alcance y las condiciones de la emergencia y son de obligado cumplimiento. Y debieran ser esas decisiones gubernamentales - sobre las que el ATC no se pronuncia porque no son el objeto recurrido - las que tuvieran rango y fuerza de ley ${ }^{12}$, no los actos simples que las integran cuyo alcance es puramente ad intra ligado a su subsiguiente tramitación, como es el caso de la autorización parlamentaria de prórroga de estado de alarma.

\section{LA TESIS DE LA STC 83/2016, DE 28 DE ABRIL, EN LA QUE EL PLENO RECHAZA EL AMPARO DE LOS CONTROLADORES AÉREOS: LAS DECISIONES DE DECLARACIÓN Y PRÓRROGA DE LOS ESTADOS EXCEPCIONALES SON ACTOS CON FUERZA DE LEY SOLO SUSCEPTIBLES DE CONTROL DE CONSTITUCIONALIDAD}

Mediante el ATS 5696/2011, de 30 de mayo, confirmado en reposición

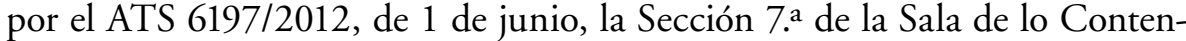
cioso-Administrativo del TS declaró la inadmisión del recurso interpuesto contra el Real Decreto 1673/2010 de Declaración del Estado de Alarma, el acuerdo del Consejo de Ministros por el que se solicitaba autorización al Congreso para prorrogarlo y el Real Decreto 1717/2010 de Prórroga. Dicha inadmisión fue recurrida en amparo ante el TC por 327 controladores aéreos, quienes fundamentaron su demanda en la violación del derecho a la tutela judicial efectiva en su vertiente de derecho de acceso a la jurisdicción, en la medida en que las resoluciones judiciales citadas habían impedido que recayera una sentencia de fondo sobre la concurrencia de los presupuestos habilitantes para proceder a la declaración y la prórroga del estado de alarma y la sumisión de los controladores a las leyes penales y disciplinares militares.

El TC admitió el recurso y avocó al Pleno su resolución debido a la especial trascendencia constitucional que revestía la caracterización jurídica de las decisiones de declaración y prórroga del estado de alarma. Por primera vez se había declarado y prorrogado un estado excepcional en nuestro país y, a resultas de

12 Así lo señalan en su voto particular los magistrados Luis Ortega Álvarez, Javier Delgado Barrio y Pablo Pérez Tremps. Pero, aunque ponen de manifiesto esta contradicción en la argumentación de la mayoría, estos magistrados consideran que ni las autorizaciones parlamentarias ni los decretos de declaración y prórroga tienen fuerza de ley, pudiendo ser las primeras controladas mediante un recurso de amparo ex art. 42 LOTC y los segundos mediante un recurso contencioso-administrativo. 
ello, por primera vez el TC debía pronunciarse sobre la naturaleza jurídica y el control jurisdiccional de estas decisiones.

En opinión de los demandantes de amparo, los reales decretos de declaración y prórroga y el acuerdo del Consejo de Ministros impugnados en la vía judicial son disposiciones administrativas plenamente fiscalizables por la jurisdicción contencioso-administrativa y no pueden considerarse decisiones o actos políticos. Ninguna de estas decisiones gubernamentales tiene valor de ley; y la autorización del Congreso de los Diputados exigida para la prórroga no pueda modificar, cambiar o transformar su naturaleza jurídica reglamentaria, por lo que su control por la jurisdicción ordinaria es debido.

Para la Abogacía del Estado, sin embargo, el acuerdo mediante el que el Gobierno solicita autorización al Congreso para prorrogar el estado de alarma es un acto de trámite no revisable jurisdiccionalmente cuyo alcance se agota en la relación entre ambos órganos constitucionales. Y también resulta forzado mantener que las decisiones de declaración y prórroga del estado de alarma tienen naturaleza reglamentaria por adoptar la forma de decreto, obviando el contexto de crisis en la que se dictan, su encuadramiento constitucional y su contenido material. Si así fuera, subraya la Abogacía del Estado, esos decretos no podrían desplazar ni exceptuar lo establecido en normas legales y menos aún condicionar el ejercicio de derechos fundamentales, de modo que no servirían como instrumento excepcional para restablecer la normalidad constitucional. El Gobierno no comunica al Congreso de los Diputados cada reglamento que dicta, ni solicita autorización parlamentaria para dictarlos o prorrogarlos. Si lo hace en el marco del derecho constitucional de excepción, es porque los decretos de declaración y prórroga de un estado excepcional no tienen esa naturaleza, ni se dictan al amparo de la potestad reglamentaria atribuida en el art. $97 \mathrm{CE}$, sino en el ejercicio de la potestad extraordinaria del Gobierno reconocida en el art. $116 \mathrm{CE}$.

En el mismo sentido, el Ministerio Fiscal considera que el acuerdo del Consejo de Ministros de solicitud de prórroga es un acto inescindible del decreto de prórroga, del que resulta un antecedente necesario. Y sobre las decisiones de declaración y prórroga del estado de alarma, su opinión es que no son reglamentos, sino disposiciones gubernamentales que, como la declaración y prórroga del estado de excepción, alcanzan materialmente eficacia de ley. Todas ellas condicionan temporalmente el ámbito de aplicabilidad de normas con rango de ley, lo que excluye toda posibilidad de fiscalización contencioso-administrativa.

Analizadas las posiciones de las partes, el TC descarta de plano cualquier control jurisdiccional del acuerdo del Consejo de Ministros por el que se solicitaba al Congreso autorización para prorrogar el estado de alarma, porque 
dicho acuerdo «no tiene otra virtualidad que la de activar el procedimiento conducente a la prórroga", cuyo contenido y efectos se circunscriben y se agotan en el estricto ámbito de relaciones entre el Gobierno y el Congreso de los Diputados, al que se dirige al solicitud. El acuerdo de solicitud no tiene ninguna incidencia sobre los derechos e intereses que los recurrentes defienden. Es un trámite y - como tal, como un acto simple que integra otro complejo- no debe ser recurrido.

Los decretos de declaración y prórroga del estado de alarma sí poseen, en cambio, una eficacia jurídica externa y pueden, por ello, ser objeto de revisión jurisdiccional, como solicitan los recurrentes. Pero para determinar el tipo de control del que son susceptibles y la jurisdicción concreta que debe realizarlo es preciso caracterizar estas decisiones gubernamentales conforme a las categorías jurídicas de nuestro sistema de fuentes. Esta es, como el TC reconoce, la cuestión nuclear suscitada por la demanda de amparo. Y a ello se dedican con rigor y solvencia dogmática los fundamentos jurídicos $10 .^{\circ}$ y $110^{\circ}$ de la STC 83/2016. Asumiendo el punto de partida del ATC 7/2012, el TC admite

[...] la existencia de ciertas decisiones o actos parlamentarios que, sin ser leyes o fuentes equiparadas a la ley, sí pueden, conforme a la propia Constitución, afectar a aquellas normas legales o asimiladas, esto es, excepcionarlas, suspenderlas o modificar su aplicabilidad. Si la Constitución y el ordenamiento habilitan a determinados actos, decisiones o resoluciones parlamentarias para modificar de tal modo la aplicación de las leyes, no es de dudar que tales actos, decisiones o resoluciones ostenten ese genérico «rango»o «valor» de ley.

Pero, en esta ocasión, determinado por el objeto recurrido, el TC da un paso más y asume, en una interpretación sistemática de la categoría de acto con fuerza de ley, que esta tesis, formulada a raíz de la impugnación de la autorización parlamentaria de prórroga del estado de alarma, no puede circunscribirse a las decisiones parlamentarias de excepción, porque esa cualidad de excepcionar, suspender o modificar la aplicabilidad de ciertas normas legales de la que son manifestación las locuciones «valor de ley», «rango de ley» o "fuerza de ley», puede atribuirse igualmente a diversos actos, decisiones o disposiciones de procedencia gubernamental. La fuerza de ley, por tanto, no es un atributo que derive del origen parlamentario de los actos, sino de su contenido y efectos sobre el ordenamiento jurídico, como había subrayado alguna doctrina (Porres Azcona, 1983: 47; García Cuadrado, 1999a: 44-49 y 1999b: 283-286; y Garrido López, 2007: 133-139 y 2008: 1248-1251). Y ello, al margen de su procedencia parlamentaria o gubernamental y de su concreta formalización jurídica. 
En este sentido, el TC señala que la decisión gubernamental por la que se declara el estado de alarma no se limita a declarar la emergencia ni a constatar la concurrencia de alguna o algunas de las situaciones o «alteraciones graves de la normalidad» previstas en el art. 4 LOAES. La decisión gubernamental tiene, además, alcance normativo, en cuanto que establece el concreto estatuto jurídico del estado declarado y habilita la adopción de disposiciones y actos administrativos. La decisión gubernamental viene, así, a integrar en cada caso, sumándose a la CE y a la LOAES, el sistema de fuentes del derecho de excepción, al precisar sus previsiones para el estado declarado. «Y esta legalidad excepcional que contiene la declaración gubernamental desplaza durante el estado de alarma la legalidad ordinaria en vigor, en la medida en que viene a excepcionar, modificar o condicionar durante ese periodo la aplicabilidad de determinadas normas, entre las que pueden resultar afectadas leyes, normas o disposiciones con rango de ley, cuya aplicación puede suspender o desplazar» (fundamento jurídico $10 .^{\circ}$ ). Aunque formalizada mediante decreto, la decisión de declarar el estado de alarma está directamente incardinada en la Constitución y, dado su contenido y efectos, posee un valor normativo equiparable al de las leyes. Es, en suma, un acto o resolución con fuerza de ley, aunque en su gestación no haya intervenido el Congreso de los Diputados.

Idéntica conclusión alcanza el TC en relación con la naturaleza jurídica del decreto gubernamental de prórroga del estado de alarma. A diferencia del decreto de declaración, el decreto de prórroga formaliza y exterioriza el acuerdo parlamentario de autorización, pero el rango y la fuerza de ley que posee para incidir sobre la legalidad no deriva de esa intervención parlamentaria, sino, al igual que ocurre con el decreto de declaración, de su propia eficacia y fuerza para suspender, exceptuar o modificar durante el período de prórroga la aplicabilidad de ciertas leyes.

Debido a la fuerza de ley de estas decisiones, las resoluciones judiciales que inadmitieron la impugnación contencioso-administrativa de los decretos de declaración y prórroga del estado de alarma no han vulnerado el derecho a la tutela judicial efectiva de los controladores aéreos en su vertiente de acceso a la jurisdicción (art. 24.1 CE), al quedar excluidas en razón de su naturaleza del ámbito de fiscalización de la jurisdicción ordinaria. Ello no supone, a juicio del TC, que los decretos de declaración y prórroga del estado de alarma resulten inmunes a todo control jurisdiccional, como sostienen los recurrentes, sino que, al poseer rango y valor de ley, solo cabe impugnarlos ante el TC a través de los procesos que tienen por objeto el control de constitucionalidad de las leyes, disposiciones normativas y actos con fuerza de ley, esto es, a través del recurso o la cuestión de inconstitucionalidad [arts. 161 y $163 \mathrm{CE}$; art. 27.2.b) LOTC]. Sin perjuicio, evidentemente, de que los actos y disposiciones 
dictados en su aplicación puedan ser revisados por la jurisdicción ordinaria en cada caso competente (art. 3.2 LOAES) y que, agotada la vía judicial, las personas afectadas puedan, asimismo, interponer recursos de amparo contra dichos actos ejecutivos cuando los estimen lesivos de sus derechos fundamentales (art. 55.2 LOTC). Unos recursos que, para garantizar plenamente el derecho a la tutela judicial efectiva, también podrían dar lugar al planteamiento de una autocuestión de inconstitucionalidad por parte del propio TC si este dudara de la constitucionalidad del decreto o resolución parlamentaria de declaración o prórroga de un estado excepcional; una duda que, pese a los argumentos de los recurrentes, no surgió en el caso enjuiciado.

Conforme al principio de congruencia, el TC podría haber concluido ahí, pero, consciente de la transcendencia de la categoría enjuiciada, no limita su pronunciamiento a la determinación de la naturaleza jurídica de la declaración y prórroga del estado de alarma. Y, trascendiendo al objeto recurrido, considera en el fundamento jurídico $11 .^{\circ}$ que los decretos gubernamentales de declaración y prórroga del estado de excepción y las resoluciones de declaración y prórroga del estado de sitio, aunque formalizados de diverso modo y adoptadas por órganos distintos, también poseen, por su contenido y efectos, la misma naturaleza de actos y resoluciones con fuerza de ley. Todas las decisiones constitucionales relativas a los tres estados excepcionales quedan, de este modo y por los mismos motivos, caracterizadas bajo una categoría común que excluye su control jurisdiccional ordinario, pero no su control de constitucionalidad.

A fin de no contradecir la doctrina del ATC 7/2012, elaborada con ocasión del recurso de amparo contra la autorización parlamentaria de la prórroga del estado de alarma, el TC también incluye de rondón a los acuerdos parlamentarios de autorización de la prórroga del estado de alarma y de declaración y prórroga del estado de excepción entre los actos con fuerza y rango de ley. Dichas autorizaciones, sin embargo, pese a determinar el contenido de la posterior declaración o prórroga, no pueden equipararse a ellas, porque carecen de eficacia jurídica ad extra. Las autorizaciones son actos necesarios ligados al siguiente trámite en el procedimiento de declaración y prórroga, pero no declaran ni prorrogan la situación crítica, ni exceptúan o suspenden la aplicabilidad de normas legales. Forman parte de los actos de declaración y prórroga con fuerza de ley, pero carecen per se de dicha fuerza. Su inclusión en la categoría es la única objeción que cabe formular a una STC que, en todo lo demás, tiene una transcendencia formidable en la medida en que identifica claramente la naturaleza jurídica de las decisiones constitucionales de excepción, las caracteriza y enmarca adecuadamente en el sistema de fuentes y residencia su control en la jurisdicción constitucional. 


\section{CONSIDERACIONES FINALES}

Las decisiones de declaración y prórroga de los estados excepcionales resultan absolutamente imprescindibles para la «realización» del derecho constitucional de excepción (arts. 55.1 y 116 de la CE), cuya efectividad está condicionada a la concurrencia y la declaración de la emergencia correspondiente. Estas decisiones presuponen la interpretación y la activación de esa normatividad constitucional latente. No son, por tanto, disposiciones reglamentarias, sino actos de naturaleza distinta directamente incardinados en la CE. Como afirma la STC 83/2016, son actos del Estado con rango y fuerza de ley que desplazan o suspenden temporalmente la aplicabilidad de otras normas legales. Pero, a diferencia de otros actos con idéntica fuerza, tienen un carácter sui generis, puesto que, en nuestro ordenamiento jurídico, las decisiones de crisis no se limitan a activar automáticamente el marco legislativo de la excepción (LOAES), sino que determinan el régimen jurídico de la concreta situación excepcional. No se incorporan al ordenamiento ni lo modifican propiamente, por lo que no son normas en sentido estricto, pero ocupan «el lugar de una verdadera norma a la hora de enjuiciar la validez de los actos administrativos que se dicten apoyándose en la declaración» (García Cuadrado, 1999a: 52). Lo decisivo en su naturaleza jurídica no es su formalización, ni el órgano legitimado para adoptarlos, sino sus efectos. Y por ellos son susceptibles de una caracterización jurídica común.

Con la excepción de la declaración del estado de alarma, que corresponde en exclusiva al Gobierno y se formaliza mediante un acto simple en forma de decreto, el resto de declaraciones y prórrogas de estados excepcionales, incluida la prórroga del estado de alarma, son actos compuestos integrados por varios actos simples o parciales en los que participan el Gobierno y el Congreso de los Diputados. Las solicitudes gubernamentales y las autorizaciones parlamentarias son secuencias consecutivas de los procedimientos de declaración y prórroga y no producen efectos jurídicos más allá de su subsiguiente tramitación. Su contenido solo será relevante cuando se incorpore a los actos complejos de declaración o prórroga de la excepción, que son los que ponen fin al procedimiento y alcanzan una eficacia jurídica ad extra. De ahí que solo las declaraciones y prórrogas, conformadas por todas y cada de las voluntades requeridas, posean una naturaleza de actos o resoluciones con fuerza de ley. Que solo ellas, y no los actos que las integran, suspendan leyes $\mathrm{y}$ alcancen incidencia constitucional. Y que solo esas decisiones de declaración y prórroga sean susceptibles de control de constitucionalidad mediante un recurso directo y también mediante una cuestión de inconstitucionalidad o autocuestión a resultas de un recurso de amparo. 
Garantizada de este modo, la CE de 1978 puede actuar como efectivo límite frente a quien decide sobre el estado de excepción, que, de otro modo, podría devenir en soberano, como señaló Schmitt en su Teología política (1998: 15). El control de constitucionalidad sobre el titular de este poder tiene sus límites, evidentemente, pero la posibilidad de que ese control se active lo protege, ante todo, de sí mismo y neutraliza las tentaciones en que el titular de la decisión pueda incurrir. Allí donde dicho control jurisdiccional está verdaderamente instituido, la amenaza de su deslegitimación pesa. Ese es el mayor y más eficaz freno del poder de excepción. Y pese a la falta de previsión competencial expresa y a la diversidad de formas y procedimientos con que se adoptan las decisiones excepcionales previstas en el art. $116 \mathrm{CE}$, cabe afirmar que este freno sobre quien declara la excepción existe en el ordenamiento constitucional español. La naturaleza jurídica de actos compuestos con fuerza de ley atribuible a dichas decisiones constitucionales críticas así lo permite, al amparo de la categoría jurídica reconocida en el art. 27.2.b) LOTC.

\section{Bibliografía}

Aba Catoira, A. (2011). El estado de alarma en España. Teoría y realidad constitucional, 28, 305-334.

Alonso Mas, M.a J. (1999). La fiscalización jurisdiccional de la actividad sin valor de ley de los Parlamentos. Madrid: Centro de Estudios Constitucionales y Constitucionales.

Álvarez García, V. (1996). El concepto de necesidad en el Derecho Público. Madrid: Civitas.

Aragón reyes, M. (2001). Acto con fuerza de ley. En M. Aragón Reyes (coord.). Temas básicos de Derecho Constitucional, tomo I (pp. 341-343). Madrid: Civitas.

Bastida Freijedo, F. J. (1998). La soberanía borrosa: la democracia. Fundamentos. Cuadernos Monográficos de Teoría del Estado, Derecho Público e Historia Constitucional, 1, 381-460.

Camus, G. (1965). L'état de nécessité en démocratie. Paris: Librairie Générale de Droit et de Jurisprudence.

Cruz Villalón, P. (1980). El estado de sitio y la Constitución. Madrid: Centro de Estudios Constitucionales y Constitucionales.

- (1981). El nuevo derecho de excepción. Revista Española de Derecho Constitucional, 2, 93-130.

- (1984). Estados excepcionales y suspensión de garantías. Madrid: Tecnos.

Fernández Segado, F. (1977). El estado de excepción en el derecho constitucional español. Madrid: Edersa.

- (1981) La Ley Orgánica de los Estados de Alarma, Excepción y Sitio. Revista de Derecho Político, 11, 83-116.

García Cuadrado, A. M. (1999a). Aproximación a una teoría de los «actos constitucionales». Revista de Derecho Politico, 46, 39-104. 
(1999b). Los actos parlamentarios con fuerza de ley. Corts. Anuario de Derecho Parlamentario, $7,275-288$.

Garrido López, C. (2007). Sobre el estado de sitio, su régimen jurídico y el control jurisdiccional de su declaración. Revista de Derecho Político, 68, 105-142. Disponible en: https://doi.org/10.5944/rdp.68.2007.9012.

(2008). Sobre la naturaleza jurídica de la declaración de los estados excepcionales previstos en el art. 116 de la CE y su control jurisdiccional. En VV. AA. Estudios sobre la Constitución Española: homenaje al profesor Jordi Solé Tura, vol. 2 (pp. 1239-1254). Madrid: Cortes Generales y Centro de Estudios Políticos y Constitucionales.

Gómez Montoro, A. J. (2005). El control jurisdiccional del Gobierno. En M. Aragón Reyes y A. J. Gómez Montoro (coords.). El Gobierno. Problemas constitucionales (pp. 471510). Madrid: Centro de Estudios Constitucionales y Constitucionales.

Jiménez Villarejo, J. (2010). La militarización de los controladores. El País, 13-12- 2010. Disponible en: http://elpais.com/diario/2010/12/13/opinion/1292194804_850215.html.

Jordano Fraga, J. (1997). ¿Jaque mate al acto político? Revista Española de Derecho Administrativo, 95, 417-446.

Kelsen, H. (1988). La garantía jurisdiccional de la Constitución (la justicia constitucional). En H. Kelsen. Escritos sobre la democracia y el socialismo (pp. 109-155). Madrid: Debate.

Lafuente Balle, J. M. ${ }^{a}$ (1990). Los estados de alarma, excepción y sitio (II). Revista de Derecho Politico, 31, 27-68.

López Guerra, L. (1988). La posición constitucional del Gobierno. En VV. AA. El Gobierno y la Administración en la Constitución, vol. I (pp. 16-33). Madrid: Instituto de Estudios Fiscales.

Mateu-Ros y Cerezo, R. (1988). Estados de alarma, excepción y sitio. En VV. AA. Gobierno y Administración en la Constitución, vol. I (pp. 165-205). Madrid: Instituto de Estudios Fiscales.

Navas Castillo, A. (1997). Los estados excepcionales y su posible control por el Tribunal Constitucional. Revista de la Facultad de Derecho de la Universidad Complutense, 87, 133-164.

- (2000). El control jurisdiccional de los actosparlamentarios sin valor de ley. Madrid: Colex.

Özbudun, M. E. (1997). Pouvoirs d'exception et contrôle juridictionnel. En VV.AA. Droits de l'homme et fonctionnement des institutions démocratiques dans des situations d'urgence (pp. 14-23). Strasbourg: Conseil de l'Europe.

— y Turhan, M. M. (1995). Les pouvoirs d'exception. Commission européenne pour la démocratie par le droit. Strasbourg: Conseil de l'Europe.

Porres Azkona, J. (1983). La decisión sobre poderes excepcionales. Revista Vasca de Administración Pública, 6, 9-72.

Punset Blanco, R. (2001). El control jurisdiccional de la actividad de las Asambleas parlamentarias y del estatuto de sus miembros en el derecho español. En R. Punset Blanco. Estudios parlamentarios (pp. 391-417). Madrid: Centro de Estudios Constitucionales y Constitucionales.

Requejo Rodríguez, P. (2012). Teoría vs. práctica del estado de alarma en España. En VV. AA. Constitución y democracia: ayer y hoy. Libro homenaje a Antonio Torres del Moral, vol. 2 (pp. 1499-1514). Madrid: Universitas. 
Rodríguez Oliver, J. M. a (1981). Los ámbitos exentos del control del Tribunal Constitucional español. En VV. AA. El Tribunal Constitucional, vol. III (pp. 2290-2359). Madrid: Instituto de Estudios Fiscales.

Santamaría Pastor, J. A. (1988). Fundamentos de Derecho Administrativo, vol. I. Madrid: Centro de Estudios Ramón Areces.

Schmitt, C. (1982). Teoría de la Constitución. Madrid: Alianza Editorial.

- (1998). Teología política. Cuatro ensayos sobre la soberanía. Buenos Aires: Editorial Struhart \& Cia.

Serrano Alberca, J. M. (1979). Situaciones excepcionales y fuentes del derecho en la Constitución española de 1978. En VV. AA. La Constitución española y las fuentes del derecho, vol. III (pp. 1957-1974). Madrid: Instituto de Estudios Fiscales.

— (2001). Comentario al art. 116. En Garrido Falla, F. (dir.). Comentarios a la Constitución, 3. ${ }^{\mathrm{a}}$ ed. (pp.1764-1817). Madrid: Civitas.

Vidal Prado, C. y Delgado Ramos, D. (2011). Algunas consideraciones sobre la declaración del estado de alarma y su prórroga. Revista Española de Derecho Constitucional, 92, 243-265. 